\title{
Article
}

\section{Artificial Sweeteners Negatively Regulate Pathogenic Characteristics of Two Model Gut Bacteria, E. coli and E. faecalis}

\author{
Aparna Shil ${ }^{1}$ and Havovi Chichger ${ }^{2, *(D)}$ \\ 1 Biomedical Research Group, School of Life Sciences, East Road, Cambridge CB1 1PT, UK; \\ aparnashil12@gmail.com \\ 2 School of Life Sciences, Anglia Ruskin University, Cambridge CB1 1PT, UK \\ * Correspondence: havovi.chichger@anglia.ac.uk
}

check for updates

Citation: Shil, A.; Chichger, $\mathrm{H}$. Artificial Sweeteners Negatively Regulate Pathogenic Characteristics of Two Model Gut Bacteria, E. coli and E. faecalis. Int. J. Mol. Sci. 2021, 22, 5228. https://doi.org/10.3390/ ijms22105228

Academic Editor: Miguel Gueimonde

Received: 19 April 2021

Accepted: 13 May 2021

Published: 15 May 2021

Publisher's Note: MDPI stays neutral with regard to jurisdictional claims in published maps and institutional affiliations.

Copyright: (c) 2021 by the authors. Licensee MDPI, Basel, Switzerland. This article is an open access article distributed under the terms and conditions of the Creative Commons Attribution (CC BY) license (https:// creativecommons.org/licenses/by/ $4.0 /)$.

\begin{abstract}
Artificial sweeteners (AS) are synthetic sugar substitutes that are commonly consumed in the diet. Recent studies have indicated considerable health risks which links the consumption of AS with metabolic derangements and gut microbiota perturbations. Despite these studies, there is still limited data on how AS impacts the commensal microbiota to cause pathogenicity. The present study sought to investigate the role of commonly consumed AS on gut bacterial pathogenicity and gut epithelium-microbiota interactions, using models of microbiota (Escherichia coli NCTC10418 and Enterococcus faecalis ATCC19433) and the intestinal epithelium (Caco-2 cells). Model gut bacteria were exposed to different concentrations of the AS saccharin, sucralose, and aspartame, and their pathogenicity and changes in interactions with Caco-2 cells were measured using in vitro studies. Findings show that sweeteners differentially increase the ability of bacteria to form a biofilm. Coculture with human intestinal epithelial cells shows an increase in the ability of model gut bacteria to adhere to, invade and kill the host epithelium. The pan-sweet taste inhibitor, zinc sulphate, effectively blocked these negative impacts. Since AS consumption in the diet continues to increase, understanding how this food additive affects gut microbiota and how these damaging effects can be ameliorated is vital.
\end{abstract}

Keywords: artificial sweeteners; microbiota; in vitro models; gut bacteria

\section{Introduction}

There are more than 100 trillion microbes in the gut which encode hundredfold more unique genes than the human genome [1,2]. There is a continued, concerted effort to further understand this, for example, with the METAgenomics of the Human Intestinal Tract collaborative project which investigates the contribution of the microbiome in providing unique protein coding genes at levels which are 360 times greater than their host $[3,4]$. The gut microbiome is in close proximity to the intestinal epithelium and, as such, epithelial cells of the intestine are exposed to diverse antigenic substances from both dietary components and gut microbiota activities. Indeed, the importance of commensal microbiota for intestinal epithelial function has already been demonstrated in germ-free mice which display a significant reduction in mucosal layer thickness and antimicrobial product levels [5-7]. Microbial metabolites from the gut microbiota, such as short-chain fatty acids (SCFA), indole, and lactate have also been shown to regulate intestinal barrier function $[8,9]$. Higher SCFA concentrations have been linked with increased gut dysbiosis, gut permeability and are indicators of various metabolic diseases, whilst improved microbial diversity showed opposite correlation with these outcomes [10]. Therefore, the gut microbiota, and associated metabolic products, play a significant role in intestinal health and wellbeing of the host.

There is a symbiotic relationship between microbiota and host where metabolic products of gut microbiota, such as B group vitamins and vitamin $\mathrm{K}$, provides essential support for human growth and development [11]. However, diet is also one of the most important 
factors that shapes gut microbiota. Studies have demonstrated that a diet which is low in fat and animal protein but rich in complex carbohydrates provides the host with a more diverse, and therefore "healthy", gut microbiome [12]. Adult healthy volunteers who consumed a large amount of animal-based diet displayed a shift in bacterial phyla composition associated with increased presence of the bile-tolerant enterotypes (Alistipes, Bilophila, and Bacteroides) and decreased the quantities of Firmicutes that metabolize plant polysaccharides (Roseburia, Eubacterium rectale, and Ruminococcus bromii) in the gut microbiota [13]. Similar observations were found comparing the intestinal microbiota of children in a rural village in Africa with an urban area in Europe, where composition of diet is dramatically impacted by the Western diet [14]. Whilst these studies demonstrate a change in bacterial phyla following long-term changes in diet, short-term exposure of healthy individuals to an energy-rich diet have been found to affect the function of the gut microbiota with negative changes observed in bacterial secretion system, protein export, and lipoic acid metabolism [12]. Interestingly, it is not only key food groups which impact on the gut microbiota. Studies demonstrate that additives, typically used to improve the taste, appearance and longevity of foods and drinks, also have an impact on the composition and function of gut bacteria [5,15]. For example, the FDA-approved dietary emulsifiers carboxymethyl cellulase and polysorbate 80 , when administered to mice at acceptable daily intake levels, increase the number of mucolytic bacteria, and decrease the number of Bacteroidetes in the gut microbiota [5]. These changes result in a reduced colonic mucin layer and, as such, several studies have demonstrated the association between emulsifier exposure and metabolic syndrome development [5]. Therefore, there is a well-established link between dietary additives, dysregulation of microbiota, and subsequent impact on gut health.

In recent years, artificial sweeteners have become popular as a non-caloric additive to sweeten foods and drinks. Artificial sweeteners, such as sucralose and aspartame, provide the sweet taste in low-calorie foods, which have increased their popularity worldwide [16]. As these sweeteners are cheap, easily available, and result in enhanced food flavour, they have been incorporated into many food products and beverages, as well as pharmaceutical products. Epidemiological studies have evidenced the beneficial role of sweeteners in weight loss and for people suffering from glucose intolerance and type 2 diabetes mellitus [16-18]; there are, however, studies which indicate opposing results. Using animal and human studies, artificial sweetener consumption has been linked with conditions leading to metabolic disease development [15]. Indeed, sweeteners were reported to induce glucose intolerance by altering the composition and function of the gut microbiota. In mice, sweetener-intake was linked with dysbiosis leading the host to be prone to symptoms related to metabolic disease. These symptoms were abrogated by treatment with the antibiotics, ciprofloxacin, metronidazole, and vancomycin, which affected the commensal microbiota and ameliorated the metabolic disease symptoms [14]. Further studies have confirmed that aspartame exposure, over 8 weeks, increases fasting glucose levels and insulin intolerance in rats [18]. These studies show that perturbed gut microbiota occurred, in response to sweetener treatment, with an increase in abundance of Enterobacteriaceae and Clostridium leptum. In a human study on 4-day food intake, the relationship between aspartame and acesulfame potassium intake and microbiota was demonstrated; no differences in the abundance and genetic composition of bacteria were noted between the artificial sweetener consumers and non-consumers, however, a significant difference in microbial diversity was observed [19]. Bian et al. demonstrated that numerous pro-inflammatory mediators were potentially produced by gut bacteria following the consumption of sweeteners in the diet, which is associated with other metabolic disease conditions like diabetes and obesity $[20,21]$. Interestingly, in gut epithelial cells, our recent studies demonstrate that exposure to artificial sweeteners increases apoptosis and permeability across the intestinal epithelium associated with inflammatory gut leak [22]. Despite controversy in the field, there is strong evidence that without changing the bacterial composition, artificial sweeteners in the diet cause changes in bacterial diversity, and potentially pathogenicity, which 
is likely to exert a negative impact to the host. However, how artificial sweeteners affect symbiotic bacteria and contribute to pathogenicity remained veiled yet.

Escherichia coli (E.coli) is the most frequent facultative anaerobic Gram-negative bacterium inhabiting the human GI tract and is a versatile pathogen whilst Enterococcus faecalis (E. faecalis) is a facultative anaerobic, Gram-positive coccus that inhabits the human GI tract [23,24]. Both E. coli and E. faecalis are commensal, as well as pathogens, and both colonise immediately after birth so are good representatives of their corresponding phyla [25]. From a technical perspective, both species can be isolated easily, grown, and maintained in the laboratory and are frequently used as potential human faecal indicators. We therefore used E. coli and E. faecalis as models to test our hypothesis that artificial sweeteners, at physiologically achievable levels in the small intestine [22,26], negatively impact bacteria in the gut microbiome. In the gut environment, both human epithelial cells and the microbiota are exposed to various concentrations of artificial sweeteners when consumed in the diet. We sought to understand the effect of commonly consumed artificial sweeteners, saccharin, sucralose, and aspartame, on two model gut bacteria (E. coli and E. faecalis) to gain an insight into the potentially pathogenic mechanisms through which sweeteners could impact the microbiota.

\section{Results}

2.1. Only the Artificial Sweetener Saccharin Affects E. coli Model Gut Bacteria Growth at High Concentrations

The effect of artificial sweeteners on E. coli and E. faecalis growth in planktonic culture was measured every $12-h$, upon exposure to varying concentrations of artificial sweetener (saccharin, sucralose, and aspartame), for 4 days. Experiments with E. coli showed no significant change in normalised growth in response to sucralose or aspartame exposure at any time point or concentration (Figure $1 \mathrm{~b}$ or c). In contrast, exposure to $1000 \mu \mathrm{M}$ saccharin significantly reduced $E$. coli growth between $48-84 \mathrm{~h}$, however lower concentrations of saccharin had no impact on E. coli growth (Figure 1a). Experiments with E. faecalis demonstrated no significant effect of either saccharin, sucralose, or aspartame, on normalised bacteria cell growth, at any time point or concentration (Figure 1d-f).
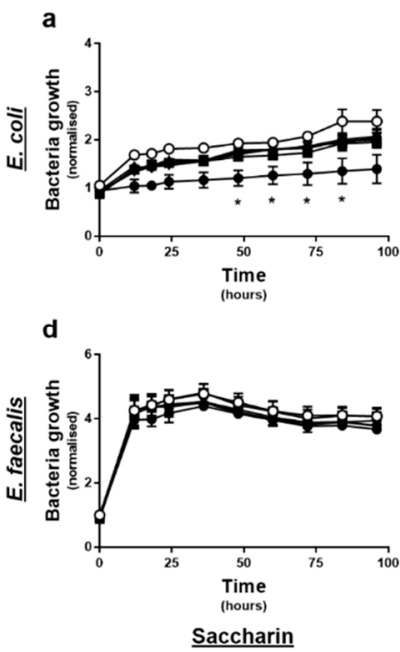

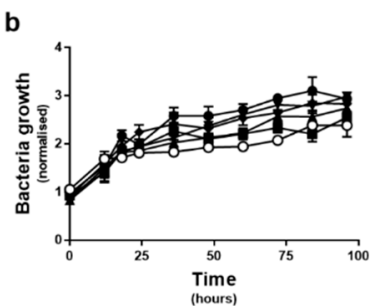

e

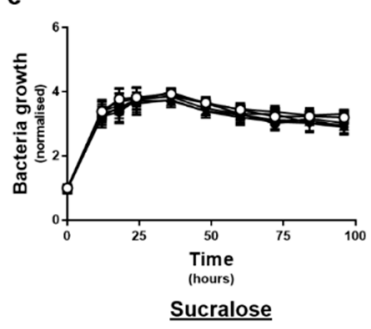

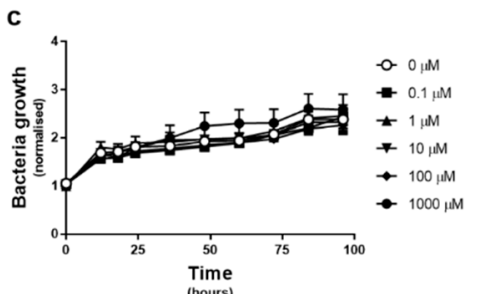

$\mathbf{f}$

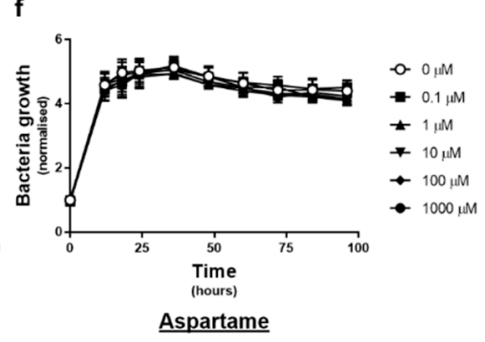

Figure 1. Only the artificial sweetener saccharin affects E. coli model gut bacteria growth at high concentrations. E. coli (panels a-c) and E. faecalis (panels $\mathbf{d}-\mathbf{f}$ ) growth was measured, following exposure to the artificial sweeteners (0 to $1000 \mu \mathrm{M})$, saccharin (panels a,d), sucralose (panels $\mathbf{b}, \mathbf{e}$ ), and aspartame (panels c,f), for up to $96 \mathrm{~h}$. Specific bacteria for each study are included in underlined text. Data are presented as mean \pm standard error mean (S.E.M.). ${ }^{*} p<0.05$ versus $0 \mu \mathrm{M}$ at the same time point. 


\subsection{Artificial Sweeteners Differentially Increase Biofilm Formation, but Not Haemolytic Activity,} in the Two Model Gut Bacteria

The ability for artificial sweeteners to regulate the pathogenicity of model gut bacteria was studied by measuring biofilm formation and haemolytic activity assays. Experiments were performed with E. coli and E. faecalis exposed to saccharin, sucralose, or aspartame at the physiological concentration of $100 \mu \mathrm{M}$; the sweeteners did not impact bacteria cell growth, except as seen with E. coli and saccharin at $1000 \mu \mathrm{M}$ (Figure 1a). Biofilm formation of $E$. coli was significantly increased, compared to the vehicle control, when bacteria were exposed to artificial sweeteners saccharin, sucralose, and aspartame (Figure 2a). Whilst biofilm formation of E. faecalis was also increased with all three artificial sweeteners, only aspartame exposure caused a significant increase in the ability of $E$. faecalis to form a biofilm (Figure 2b). In contrast, the haemolysis assay indicated that artificial sweeteners saccharin, sucralose, and aspartame had no effect on qualitative (Figure 2c (i)) or semi-quantitative (Figure 2c (ii)) haemolysin production of either E. coli or E. faecalis, in contrast to the positive control, the haemolytic bacteria S. aureus.

a

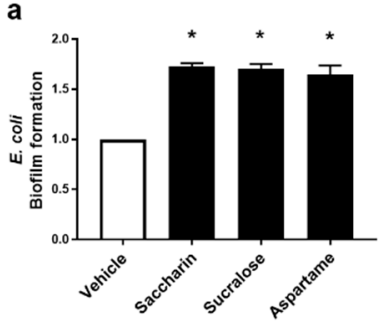

c i)

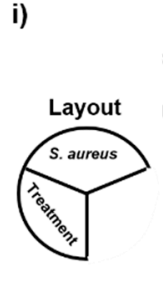

b

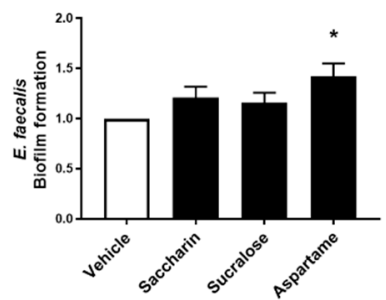

Saccharin

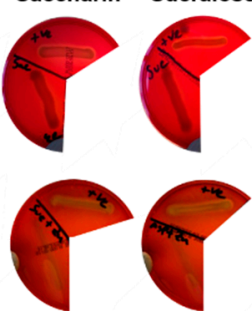

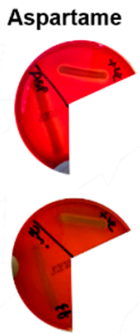

ii)

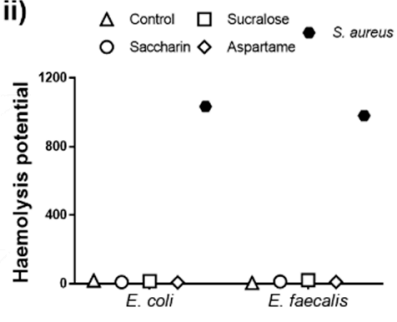

Figure 2. Artificial sweeteners differentially increase biofilm formation, but not haemolytic activity, in the two model gut bacteria. E. coli (panel a) and E. faecalis (panel b) were exposed to artificial sweeteners, saccharin, sucralose, and aspartame $(100 \mu \mathrm{M})$ for $24 \mathrm{~h}$ (panels a,b) or $48 \mathrm{~h}$ (panel c) and biofilm formation or haemolysis assay, respectively, were performed. For the haemolysis assay, S. aureus was used as a positive control to show haemolysin release (panel c) using representative images (panel c (i)) and semi-quantification (panel c (ii)) of haemolysis. Specific bacteria for each study are included in underlined text. Data are presented as mean \pm S.E.M for panel $\mathrm{a}$ and $\mathrm{b}$ and as mean only for panel c. ${ }^{*} p<0.05$ versus vehicle for biofilm formation.

\subsection{Artificial Sweeteners Significantly Disrupt the Interaction between Model Gut Bacterial and Intestinal Epithelial Cells}

To further understand the physiological effect of artificial sweeteners on model gut bacteria, E. coli and E. faecalis, the next studies used a co-culture system with the intestinal epithelial cell line, Caco-2 cells. Studies measured the effect of saccharin, sucralose, and aspartame in regulating the ability of model gut bacteria to adhere to, invade, and kill intestinal epithelial cells.

Intact $E$. coli or $E$. faecalis, which were pre-exposed to artificial sweeteners, were incubated with Caco- 2 cells to establish adhesion ability of the model gut bacteria. All three artificial sweeteners studied, saccharin, sucralose, and aspartame, significantly increased adhesion of both E. coli and E. faecalis to intestinal epithelial cells (Figure 3a,d). Interestingly, a more dramatic fold-increase in bacterial adhesion to Caco-2 cells was observed with E. faecalis compared to $E$. coli for saccharin (E. coli $2.3 \pm 0.4$ versus E. faecalis $5.2 \pm 2.1$ ), 
sucralose (E. coli $2.0 \pm 0.3$ versus E. faecalis $5.4 \pm 1.8)$, and aspartame (E. coli $2.9 \pm 0.7$ versus E. faecalis $6.6 \pm 1.9)$.
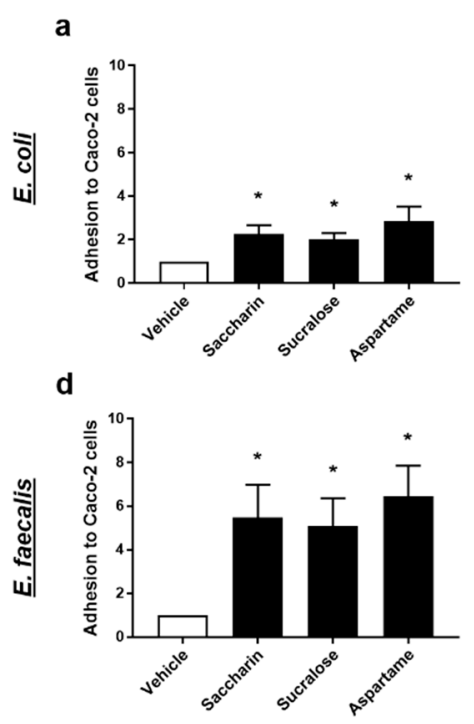

b

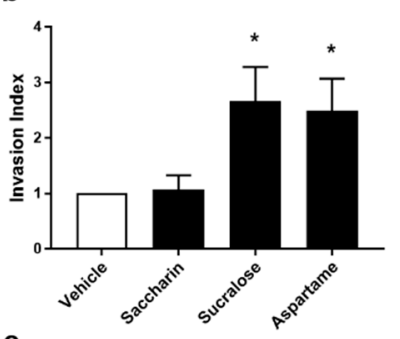

e

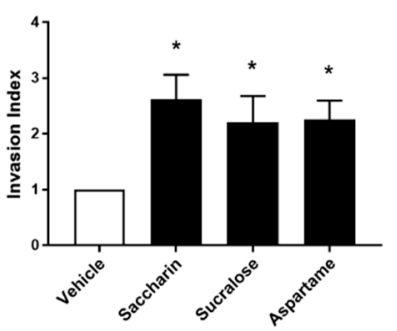

C

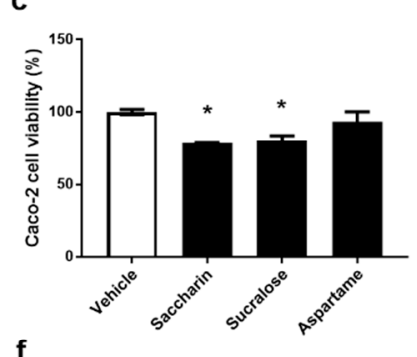

f

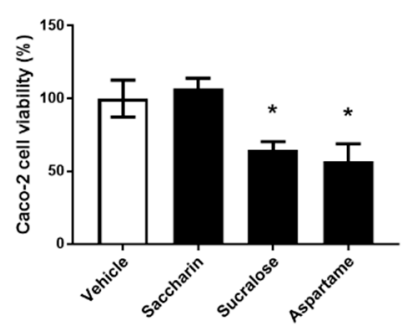

Figure 3. Artificial sweeteners significantly disrupt the interaction between model gut bacterial and intestinal epithelial cells. E. coli (panels a-c) and E. faecalis (panels $\mathbf{d}-\mathbf{f}$ ) were exposed to artificial sweeteners, saccharin, sucralose, and aspartame $(100 \mu \mathrm{M})$, for $24 \mathrm{~h}$. Adhesion of bacteria to Caco-2 cells (panels a,d) and invasion of bacteria into Caco-2 cells (panels $\mathbf{b}, \mathbf{e}$ ) were measured following incubation with Caco- 2 cells for $1 \mathrm{~h}$. Cytotoxic effects of bacterial soluble factors were assessed by culturing bacterial supernatant with Caco-2 cells for $24 \mathrm{~h}$ (panels c,f). Specific bacteria for each study are included in underlined text. Data are presented as mean \pm S.E.M. ${ }^{*} p<0.05$ versus vehicle.

The ability of model gut bacteria, E. coli and E. faecalis, to invade Caco-2 cells was measured following exposure to artificial sweeteners. Sucralose and aspartame exposure significantly increased the invasion index of both E. coli and E. faecalis (Figure 3b,e). In contrast, incubation with saccharin had a significant effect on the invasive ability of E. faecalis (Figure 3e) but not E. coli (Figure 3b). Soluble bacterial factors released from E. coli or E. faecalis exposed to artificial sweeteners were incubated with Caco-2 cells and cytotoxicity was measured. Soluble factors secreted from E. coli exposed to saccharin and sucralose, but not aspartame, induced a small but significant reduction in Caco-2 cell viability (Figure 3c). In contrast, E. faecalis exposed to sucralose and aspartame, but not saccharin, released soluble factors which significantly lowered Caco-2 cell viability (Figure 3f).

\subsection{Artificial Sweeteners Impact Model Gut Bacteria through a Taste Sensing Mechanism}

Our final experiments sought to understand how artificial sweeteners regulated the model gut bacteria pathogenic functions studied: biofilm formation, adhesion and invasion ability, and cytotoxicity. Given the lack of published literature in the field, there is no specific taste receptor established in bacteria. The pan taste inhibitor, zinc sulphate, was used to establish the potential of a taste sensing mechanism in E. coli and E. faecalis [27]. At a range of concentrations, zinc sulphate has no impact on growth of either model gut bacteria (Figure 4a). Zinc sulphate also had no impact on biofilm formation, adhesive or invasive ability of either bacteria in the absence of sweeteners (vehicle-treated E. coli or E. faecalis) (Figure $4 \mathrm{~b}-\mathrm{g}$ ). In E. coli, zinc sulphate significantly reduced sweetener-induced biofilm formation (Figure $4 \mathrm{~b}$ ) and adhesive ability (Figure 4c). Furthermore, aspartame- and sucralose-mediated increase in the ability of $E$. coli to invade Caco-2 cells was attenuated by zinc sulphate (Figure 4d). In E. faecalis, zinc sulphate attenuated biofilm formation induced by aspartame (Figure 4e) and all sweetener-induced effects on bacterial adhesion and invasion of Caco-2 cells (Figure 4f,g). The cytotoxic effect on Caco-2 cells, induced by saccharin and sucralose exposure with E. coli (Figure 3c) and sucralose and aspartame 
exposure with E. faecalis (Figure 3f), was also blocked by exposure to zinc sulphate (data not shown).

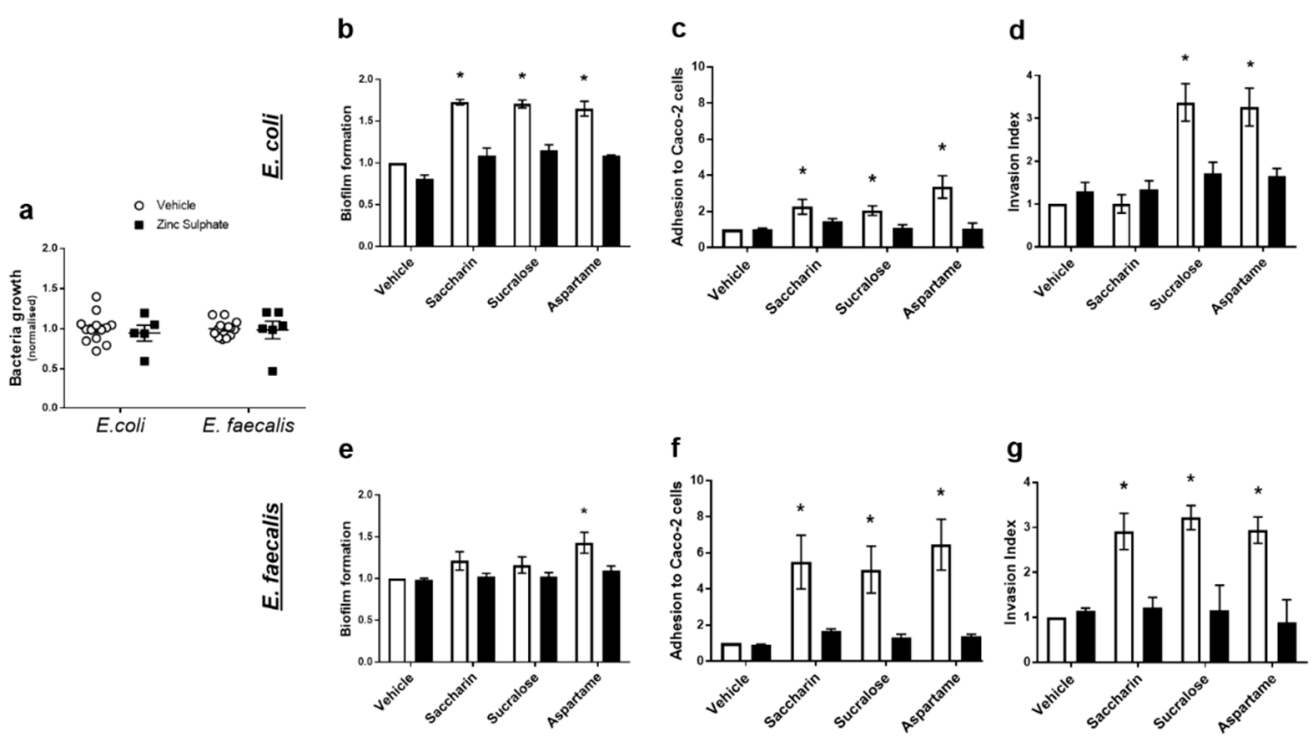

Figure 4. Artificial sweeteners impact model gut bacteria through a taste sensing mechanism. E. coli and E. faecalis were exposed to zinc sulphate $(100 \mu \mathrm{M})$ for $24 \mathrm{~h}$ and growth was measured (panel a). Alternatively, E. coli (panels b-d) and E. faecalis (panels e-g) were exposed to artificial sweeteners, saccharin, sucralose, and aspartame $(100 \mu \mathrm{M})$, for $24 \mathrm{~h}$ in the presence or absence of zinc sulphate $(100 \mu \mathrm{M})$. Subsequent measurements were made to assess biofilm formation (panels $\mathbf{b}, \mathbf{e})$ ), adhesion to (panels $\mathbf{c}, \mathbf{f}$ ) and invasion of (panels $\mathbf{d}, \mathbf{g}$ ) Caco-2 cells. Specific bacteria for each study are included in underlined text. Data are presented as mean \pm S.E.M. ${ }^{*} p<0.05$ versus vehicle for sweeteners.

Taken together, findings demonstrate the effect of artificial sweeteners, saccharin, sucralose, and aspartame, in increasing the pathogenicity of model gut bacteria, E. coli and E. faecalis, through a taste-dependent pathway. Further studies are needed to understand the molecular mechanisms responsible for these pathogenic effects with the aim of reducing the negative impact of sweeteners on gut health.

\section{Discussion}

Artificial sweeteners are commonly consumed in the diet as an aid for weight loss however there is still controversy on the potential benefits versus detrimental effects of these compounds on gut health. Previous studies have demonstrated the impact of sweeteners on diversity of gut microbiota $[15,19,28]$. These studies indicate an increase in bacteria, such as Enterobacteriaceae, of which E. coli is one, however this has been studied in whole microbiome rather than at the individual bacteria or molecular level. In the present study, we use an in vitro model of the gut and the microbiota to investigate the impact of sweeteners on potential changes in pathogenicity. Our studies demonstrate that saccharin, sucralose, and aspartame at the physiological concentration of $100 \mu \mathrm{M}$, which could be easily achieved in the diet $[15,22]$, differentially increase biofilm formation as well as the ability of bacteria to adhere to, invade and kill mammalian gut epithelial cells. These findings indicate that saccharin, sucralose, and aspartame all promote pathogenic changes in two model gut bacteria, E. coli and E. faecalis, which could worsen the effect of consuming artificial sweeteners in the diet on gut health.

Bacterial growth is one of the most well-studied characteristics of metabolism. Planktonic growth of E. coli and E. faecalis showed little effect from exposure to artificial sweeteners at a range of concentrations. The exception to this is saccharin at $1 \mathrm{mM}$ concentration which caused bacteriostatic effects in E. coli from 48 to $84 \mathrm{~h}$. These findings differ from those in the literature where Wang et al. established that saccharin, sucralose, and acesulfame $\mathrm{K}$ 
have bacteriostatic effects on E. coli HB101 and K-12 strains [29]. Importantly, this study was performed with supraphysiological sweetener concentrations in the $30-80 \mathrm{mM}$ range which may explain the difference in findings [16]. Our studies also demonstrate that all three sweeteners evaluated (saccharin, sucralose, and aspartame) increased biofilm formation of $E$. coli with only aspartame affecting biofilm formation of E. faecalis. Bacteria typically transition from planktonic to biofilm as a result of environmental and physiological cues, including cell density, nutrient availability, and cellular stress. Bacteria growing in biofilms are less sensitive to antimicrobial resistance treatment and are more likely to express more virulence factors and exotoxins compared to planktonic cells [30-32]. These virulence factors may be related to those causing increased adhesion to and invasion of Caco-2 cells and elevated cytotoxic effects, as we observed in the present study. It is, however, worth noting that we did not note the same pattern of sweetener effect for the different pathogenicity measurements made for each bacterium. For example, in studies with $E$. coli we established that all 3 sweeteners studied cause an increase in biofilm formation and adhesion to Caco-2 cells. However, only sucralose and aspartame affected bacterial invasion and soluble factors from only saccharin- and sucralose-treated E. coli decreased Caco-2 cell viability. Therefore, sweeteners have differential effects on pathogenicity in $E$. coli and E. faecalis.

There are a range of virulence factors which bacteria can utilise to become pathogenic to a host, such as prevention of complement activation and escape from phagosomes. Some pathogenic $E$. coli have been shown to display a range of virulence factors, such as bundle-forming pilus (BFP), type 1 pili and cytolysin A (ClyA), to cause adherence and invasion of host cells, and the production of cytotoxins which kill host cells [33-35]. Similarly, pathogenic E. faecalis shows adhesion and invasion of intestinal epithelial cells, via pili and aggregation substances, such as AsaI and glycolipids, and cytotoxicity via secreted factors, such as cytolysin [36-39]. Other mechanisms of pathogenicity have also been identified. E. coli can exert pathogenic effects, such as biofilm formation, through yafK and Fis gene expression, and $\alpha$ - or $\beta$-haemolysis, potentially through a ClyA-mediated pathway $[40,41]$. Similarly, biofilm formation and haemolysis activity have been shown in pathogenic E. faecalis by the xdh or Esp genes and $\beta$-haemolysin, respectively [42-44]. Whilst artificial sweeteners have been shown to affect dysbiosis in the gut microbiota, there are limited mechanistic studies which show pathogenic responses of individual bacteria to sweeteners. In the present study, we demonstrate that the artificial sweeteners saccharin, sucralose, and aspartame, at physiological concentrations, impact on all these pathogenic mechanisms except $\beta$-haemolysis. The model bacteria, E. coli and E. faecalis, are $\alpha$ - and $\gamma$-haemolytic, respectively, in normal conditions, however, they can turn into $\beta$-haemolytic when pathogenic $[44,45]$. It is possible that we noted no change in haemolysis because of the in vitro nature of the study or the use of laboratory strains of each bacteria. Indeed, clinical isolates of $E$. coli or E. faecalis have been shown to display haemolytic genes, such as hly and ClyA [46,47], which are likely to be lacking from the bacteria we studied. It is also worth noting that model gut bacteria were exposed to artificial sweeteners for $24 \mathrm{~h}$, so only the long-lasting response to the additive was recorded. However, given that artificial sweeteners are consistently present in the diet, in a range of sources from food, drink, and cosmetics, it is likely that the microbiome would be continuously exposed and long-lasting responses are most accurate to study. Further study on the genetic changes of each bacteria, following exposure to saccharin, sucralose, and aspartame, may provide a deeper molecular understanding of the mechanisms regulating their pathogenicity.

In mammals, sweet taste molecules are recognised via the sweet taste receptor heteroor homo-dimer, T1R2/T1R3 or T1R3/T1R3, respectively [48]. Zinc sulphate is a potent inhibitor of sweet taste sensing which is hypothesised to act through the zinc ion binding to T1R2/T1R3 or T1R3/T1R3 and altering the conformation of the receptor to prevent sweeteners from interacting with it [27]. Our studies demonstrate that zinc sulphate can effectively block the impact of sweeteners on pathogenicity for both E. coli and E. faecalis. This indicates the presence of a sweet taste sensor in bacteria through which sweeteners can 
activate pathogenic effects, however, sucralose has a perceived sweet taste intensity which is 2-times higher than saccharin and 3-times higher than aspartame [49]. Our findings demonstrate differential effects of the three sweeteners on biofilm formation, adhesion and invasion, and cytotoxicity in E. coli and E. faecalis. Therefore, it is likely that these bacteria are responding independently of traditional taste sensing pathways. Indeed, whilst studies indicate the potential for olfactory responses in Bacillus licheniformis, there is no literature indicating the presence of a sweet taste receptor or sensor in bacteria which could respond to artificial sweeteners [50]. Instead, there is evidence that sweeteners can cause DNA damage in bacteria, elevate bacterial mutation rate in a dose-dependent manner or ROS production and detoxification, and increase cell membrane permeability [51-54]. ROS can modulate the quorum sensing ability of bacteria to sense and respond to their environment $[55,56]$ therefore sweeteners may impact pathogenicity of model gut bacteria in the present study through a ROS-dependent pathway.

Bacteria such as E. faecalis have been shown to translocate across the intestinal wall, disseminate into the blood stream, and cause septicaemia along with congregation in the mesenteric lymph nodes, liver, and spleen [57-59]. In our present study, we demonstrate that saccharin, sucralose, and aspartame increased the ability of model gut bacteria to adhere to and invade intestinal epithelial cells, with the exception of saccharin which has no significant effect on E. coli invasion. Furthermore, we and others have previously demonstrated the negative effect of artificial sweeteners, saccharin, sucralose, and aspartame, on intestinal epithelial cell apoptosis and permeability $[22,60]$, thus further increasing the opportunity for bacteria to traverse the gut epithelium and cause septicaemia. However, to date, no studies have been performed to study the link between consumption of artificial sweeteners correlates with incidence of septicaemia.

Globally, sweeteners (acesulfame, saccharin, and sucralose) have been detected in wastewater, surface water, groundwater, and drinking water systems [61-63]. More worryingly, artificial sweeteners have been linked to increased horizontal transfer of antimicrobial resistance genes in environmental and clinical settings [52,54]. In addition, increased biofilm formation is believed to cause medical device-associated infections and is closely linked to the antibiotic-resistant bacteria, which is now a widespread public health threat [64-67]. Understanding the role of sweeteners in regulating biofilm formation, as well as other pathogenic effects on the intestinal epithelium and antimicrobial resistance of bacteria, could have a dramatic impact on public health in a multitude of ways.

\section{Materials and Methods}

\subsection{Materials}

Enterococcus faecalis (E. faecalis, 19433 ${ }^{\mathrm{TM}}$ ) and Escherichia coli (E. coli, 10418) were purchased from ATCC (Middlesex, UK) and NCTC (Salisbury, UK), respectively. Staphylococcus aureus, for use as positive control for the haemolysis assay, was a kind gift from Dr. Christopher O'Kane (Anglia Ruskin University). Bacterial media and blood agar plates was purchased from Oxoid (ThermoFisher, Hampshire, UK). For bacterial growth curve experiment and biofilm assay, sterile, flat-bottom, non-treated polystyrene 96-well plates were purchased from CytoOne (StarLabs, Milton Keynes, UK). Phosphate Buffered Saline (PBS) was obtained from Gibco (ThermoFisher, Hampshire, UK). Human colon adenocarcinoma cells (Caco-2, 86010202), Eagle's Minimal Essential Media (EMEM), zinc sulphate, antibiotics, and artificial sweeteners (saccharin, sucralose, and aspartame) were purchased from Sigma-Aldrich (Dorset, UK).

\subsection{Bacterial and Mammalian Cell Culture}

Bacterial cells were grown aseptically at $37^{\circ} \mathrm{C}$ on solid media for single colonies, or in liquid media with shaking $(150 \mathrm{rpm})$ for growth measurements. Brain Heart Infusion agar and Nutrient Agar were used as solid, and Brain Heart Infusion and Nutrient broth were used as liquid media for E. faecalis and E. coli, respectively, as guided by the supplier. 
A human intestinal epithelial cell line, Caco-2 cells, was used for the interaction assays, such as adhesion, invasion, and cytotoxicity assays. Monolayers of Caco-2 cells were grown aseptically in EMEM supplemented with $10 \%$ foetal bovine serum and $1 \%$ antibiotic $\left(1 \mathrm{U} / \mathrm{mL}\right.$ penicillin, $1 \mu \mathrm{g} / \mathrm{mL}$ streptomycin) solution at $37^{\circ} \mathrm{C}$ in $5 \% \mathrm{CO}_{2}$.

\subsection{Growth Curve Determination}

A single bacterial colony of E. coli or E. faecalis was inoculated aseptically into Nutrient broth or Brain-heart infusion, respectively, supplemented with the artificial sweeteners, saccharin, sucralose, and aspartame at ranging concentrations from 0.1 to $1000 \mu \mathrm{M}$, or vehicle (double-distilled water $\left(\mathrm{ddH}_{2} \mathrm{O}\right)$ ) and allowed to grow for up to 4 days. Growth was recorded as absorbance at $600 \mathrm{~nm}\left(\mathrm{~A}_{600}\right)$ using the Victor ${ }^{\mathrm{TM}} \mathrm{X} 3$ (Perkin Elmer) and values were normalised to $0 \mu \mathrm{M}$ at $0 \mathrm{~h}$ (as 1 ).

\subsection{Biofilm Formation Assay}

Biofilm formation of E. coli and E. faecalis was measured after exposure to artificial sweeteners, saccharin, sucralose, and aspartame $(100 \mu \mathrm{M})$ using crystal violet biofilm formation assay as described previously [68] with some modifications. A single bacterial colony was inoculated into $10 \mathrm{~mL}$ of the corresponding liquid media supplemented with sweetener or vehicle $\left(\mathrm{H}_{2} \mathrm{O}\right)$ in presence or absence of zinc sulphate. Absorbance at $600 \mathrm{~nm}$ was measured on a Victor ${ }^{\mathrm{TM}} \mathrm{X} 3$ multiplate reader to ensure equal bacterial cell numbers, and overnight culture was transferred into liquid media (1:200) supplemented with artificial sweeteners. After vortexing, $200 \mu \mathrm{L}$ was transferred into sterile 96-well plasticware plates and grown aerobically for $48 \mathrm{~h}$ at $37^{\circ} \mathrm{C}$. The supernatant was removed, and wells were washed twice with $\mathrm{ddH}_{2} \mathrm{O}$ to remove loosely associated bacteria. Each well was stained with $150 \mu \mathrm{L} 0.1 \%$ Gram crystal violet for $20 \mathrm{~min}$ at room temperature. After staining, wells were washed with $\mathrm{ddH}_{2} \mathrm{O}$ three times. The retained crystal violet by the biofilms were brought into solution by adding $200 \mu \mathrm{L} \mathrm{30 \%}$ acetic acid and incubating at $37^{\circ} \mathrm{C}$ for $5 \mathrm{~min}$. The quantitative analysis of biofilm formation was performed by measuring absorbance at $600 \mathrm{~nm}$ using the multiplate reader (Victor ${ }^{\mathrm{TM}} \mathrm{X} 3$ ). The biofilm forming unit was calculated by dividing the absorbance of crystal violet retained with the absorbance of the total bacterial growth and was normalised to the control (as 1).

\subsection{Haemolysis Assay Using Blood Agar Plates}

Blood Agar plate with 7\% Horse Blood was used to investigate the haemolytic properties of E. coli and E. faecalis after exposure to artificial sweeteners. Bacteria were exposed to the artificial sweeteners, saccharin, sucralose, and aspartame $(100 \mu \mathrm{M})$ for $24 \mathrm{~h}$, in the presence and absence of zinc sulphate $(100 \mu \mathrm{M})$ under shaking conditions at $37^{\circ} \mathrm{C}$. Absorbance of bacteria was assessed at $600 \mathrm{~nm}$ and bacteria number was normalised prior to plating on blood agar plates. Plates were incubated at $37^{\circ} \mathrm{C}$ and haemolysis was assessed at $24 \mathrm{~h}$ alongside Staphylococcus aureus as a positive control [69]. Images of the plates were taken using UVI-Tec imager (Uvitec Ltd., Cambridge, UK). To perform semi-quantitative analysis of the haemolysis assay, images were assessed using ImageJ $1.51 \mathrm{~s}$ (http:/ /imagej.nih.gov/ij, 19 March 2021). For each streak, the area of the bacteria and the haemolysis area on the blood agar plates was measured in relative units and the haemolytic potential was calculated as the haemolysis area minus the bacteria area.

\subsection{Adhesion Assay}

Adhesion of the model gut bacteria to Caco-2 cells following artificial sweetener exposure was measured as previously described [70] with some modifications. Caco-2 cells were seeded on 24-well tissue culture plates $\left(7.5 \times 10^{4}\right.$ cells $/$ well $)$ and incubated in humidified condition (90\%) at $37^{\circ} \mathrm{C}$ and $5 \% \mathrm{CO}_{2}$ for $48 \mathrm{~h}$, following exposure to artificial sweeteners for $24 \mathrm{~h}$. Meanwhile, a single colony of E. coli and E. faecalis was inoculated into $10 \mathrm{~mL}$ of respective media supplemented with the artificial sweeteners in the presence or absence of zinc sulphate, or vehicle $\left(\mathrm{ddH}_{2} \mathrm{O}\right)$ and incubated overnight at $37^{\circ} \mathrm{C}$ with 
shaking at $150 \mathrm{rpm}$. Bacteria were then washed twice with $500 \mu \mathrm{L}$ serum and antibiotic-free EMEM media by centrifuging at $4000 \mathrm{rpm}(2683 \times \mathrm{g})$ for $10 \mathrm{~min}$ at $37^{\circ} \mathrm{C}$ (accuSpinTM $1 \mathrm{R}$, Fisher Scientific, Thermo Electron Corporation LED GmbH, Osterode, Germany) and re-suspended in EMEM without antibiotics.

Caco-2 cell monolayers were washed twice with $500 \mu \mathrm{L}$ PBS, and then EMEM $(490 \mu \mathrm{L}$; without antibiotics) was added to each well. The total number of adherent Caco-2 cells was measured by performing a cell count. Bacterial suspension $(10 \mu \mathrm{L})$ was added on the Caco-2 cells at a multiplicity of infection (MOI) 1:300 for an infection incubation time of $1 \mathrm{~h}$. After the infection period, the cells were washed twice with $500 \mu \mathrm{L}$ of sterile PBS, the Caco- 2 cells were lysed with $500 \mu \mathrm{L}$ of $0.5 \%$ Triton X-100 by pipetting up and down. The number of viable bacteria was determined by spread-plating serial dilutions of the cell suspension on respective solid media, followed by overnight incubation at $37^{\circ} \mathrm{C}$ and counting colony forming units. Bacterial adhesion was expressed as ratio of total bacteria attached per viable Caco-2 cells (normalised to 1). Each assay was performed in triplicate with the successive passage of Caco-2 cells.

\subsection{Invasion Assay}

Caco-2 cells were seeded on 24-well tissue culture plates at a density of $7.5 \times 10^{4}$ cells/well for $36 \mathrm{~h}$ followed by exposure to artificial sweeteners for $24 \mathrm{~h}$ at $37^{\circ} \mathrm{C}$ in humidified condition with $5 \% \mathrm{CO}_{2}$. The cell monolayer was washed twice with $500 \mu \mathrm{L}$ sterile PBS and $490 \mu \mathrm{L}$ fresh EMEM media without antibiotics was added. Bacterial invasion of Caco-2 cells was measured using the antibiotic protection assay previously described [71] with some modifications. Bacteria were exposed to the artificial sweeteners and prepared for infection, as described in Section 4.6. The number of adhered Caco-2 cells that were subjected to bacterial infection was determined by performing a cell count. Caco-2 cell monolayer was infected with bacteria at MOI 1:300 for $1 \mathrm{~h}$ at $37^{\circ} \mathrm{C}$. The monolayer was washed once with $500 \mu \mathrm{L}$ PBS and fresh cell culture medium $(500 \mu \mathrm{L})$ was added containing $100 \mu \mathrm{g} / \mathrm{mL}$ gentamicin for E. coli and $100 \mu \mathrm{g} / \mathrm{mL}$ gentamicin along with $50 \mu \mathrm{g} / \mathrm{mL}$ ampicillin for E. faecalis and incubated at $37^{\circ} \mathrm{C}$ for $30 \mathrm{~min}$ to kill the external-adhered bacteria [71]. The cell monolayer was washed twice with PBS and then lysed with $0.5 \%$ Triton X-100 in PBS.

The number of viable colony-forming units were determined by diluting and plating the samples onto solid media and incubating overnight at $37^{\circ} \mathrm{C}$. The results were expressed as the ratio of intracellular bacteria compared with the control (normalized to 1). Each assay was performed in triplicate with the successive passage of Caco-2 cells.

\subsection{Cytotoxicity Assay}

The cytotoxic effect of AS-mediated bacterial metabolites on intestinal epithelial cells was performed following the protocol previously described [72] with modifications, and cell viability was measured by using the Cell Counting Kit-8 (CCK-8), as per manufacturer's guidelines. Caco- 2 cells were grown on 96-well plates $\left(1 \times 10^{4}\right.$ cells/well) and incubated for $48 \mathrm{~h}$ at $37{ }^{\circ} \mathrm{C}$ in humidified condition with $5 \% \mathrm{CO}_{2}$. Simultaneously, E. coli or E. faecalis was grown in $10 \mathrm{~mL}$ of respective liquid media supplemented with $100 \mu \mathrm{M}$ of artificial sweeteners with or without $100 \mu \mathrm{M} / \mathrm{mL}$ zinc sulphate or vehicle for $24 \mathrm{~h}$. The cultures were centrifuged at $4000 \mathrm{rpm}(2683 \times \mathrm{g})$ for $15 \mathrm{~min}$ at $4{ }^{\circ} \mathrm{C}$ and supernatant was collected, filter-sterilized ( $0.22 \mu \mathrm{M}$ membranes; Millipore, USA). $50 \mu \mathrm{L}$ of the soluble bacterial factors (supernatant) and $50 \mu \mathrm{L}$ EMEM without antibiotics was added to the pre-washed (with $100 \mu \mathrm{L}$ of sterile PBS) Caco- 2 cell monolayer. Cells were incubated for $24 \mathrm{~h}$ followed by measurement of cell viability using CCK-8 reagent assessed as absorbance at $450 \mathrm{~nm}$ using a microplate reader (Tecan Sunrise ${ }^{\mathrm{TM}}$, Denmark, Switzerland).

\subsection{Statistical Analysis}

All the quantitative data was collected as Excel (Microsoft Office) files. The average of triplicates for each study were analysed as $n=1$ with $n=5-6$ for all studies except the haemolysis assay. Data were analysed using GraphPad Prism 7. Statistical analysis was 
performed using either a one-way ANOVA or a two-way ANOVA, with Tukey multiple comparisons post-hoc test where relevant. Significance was reached when $p<0.05$.

Author Contributions: A.S.: Conceptualisation, Methodology, Validation, Formal analysis, Investigation, Data Curation, Writing-Original Draft Preparation, Writing-Review and Editing. H.C.: Conceptualisation, Resources, Formal analysis, Writing-Original Draft Preparation, Writing-Review and Editing, Supervision, Project Administration. All authors have read and agreed to the published version of the manuscript.

Funding: This research received no external funding. The APC was funded by Anglia Ruskin University Open Access Fund.

Institutional Review Board Statement: There are no animal or human studies included however ethical approval for in vitro studies was obtained from the School of Life Sciences Ethics Panel, Anglia Ruskin University from 23 March 2016 to 1 June 2019.

Informed Consent Statement: Not applicable.

Data Availability Statement: Data sharing not applicable.

Conflicts of Interest: The authors declare no conflict of interest.

\section{References}

1. Ley, R.E.; Peterson, D.A.; Gordon, J.I. Ecological and evolutionary forces shaping microbial diversity in the human intestine. Cell 2006, 124, 837-848. [CrossRef]

2. Wekerle, H. Brain autoimmunity and intestinal microbiota: 100 trillion game changers. Trends Immunol. 2017, 38, 483-497. [CrossRef]

3. Li, J.; Jia, H.; Cai, X.; Zhong, H.; Feng, Q.; Sunagawa, S.; Arumugam, M.; Kultima, J.R.; Prifti, E.; Nielsen, T.; et al. An integrated catalog of reference genes in the human gut microbiome. Nat. Biotechnol. 2014, 32, 834-841. [CrossRef]

4. Qin, J.; Li, R.; Raes, J.; Arumugam, M.; Burgdorf, K.; Manichanh, C.; Nielsen, T.; Pons, N.; Levenez, F.; Yamada, T.; et al. A human gut microbial gene catalogue established by metagenomic sequencing. Nature 2010, 464, 59-65. [CrossRef] [PubMed]

5. Chassaing, B.; Koren, O.; Goodrich, J.K.; Poole, S.; Srinivasan, S.; Ley, R.E.; Gewirtz, A.T. Dietary emulsifiers impact the mouse gut microbiota promoting colitis and metabolic syndrome. Nature 2015, 519, 92-96. [CrossRef] [PubMed]

6. Petersson, J.; Schreiber, O.; Hansson, G.C.; Gendler, S.J.; Velcich, A.; Lundberg, J.O.; Roos, S.; Holm, L.; Philipson, M. Importance and regulation of the colonic mucus barrier in a mouse model of colitis. Am. J. Physiol. Gastrointest. Liver Physiol. 2011, $300,2$. [CrossRef] [PubMed]

7. Vaishnava, S.; Behrendt, C.L.; Ismail, A.S.; Eckmann, L.; Hooper, L.V. Paneth cells directly sense gut commensals and maintain homeostasis at the intestinal host-microbial interface. Proc. Natl. Acad. Sci. USA 2008, 10552, 20858-20863. [CrossRef] [PubMed]

8. Kelly, C.J.; Zheng, L.; Campbell, E.L.; Saeedi, B.; Scholz, C.C.; Bayless, A.J.; Wilson, K.E.; Glover, L.E.; Kominsky, D.J.; Magnuson, A.; et al. Crosstalk between microbiota-derived short-chain fatty acids and intestinal epithelial HIF augments tissue barrier function. Cell Host Microbe 2015, 175, 662-671. [CrossRef] [PubMed]

9. Iraporda, C.; Errea, A.; Romanin, D.E.; Cayet, D.; Pereyra, E.; Pignataro, O.; Sirard, J.C.; Garrote, G.L.; Abraham, A.G.; Rumbo, M. Lactate and short chain fatty acids produced by microbial fermentation downregulate proinflammatory responses in intestinal epithelial cells and myeloid cells. Immunobiology 2015, 22010, 1161-1169. [CrossRef]

10. de la Cuesta-Zuluaga, J.; Mueller, N.T.; Alvarez-Quintero, R.; Velasquez-Meija, E.P.; Sierra, J.A.; Corrales-Agudelo, V.; Carmona, J.A.; Abad, J.M.; Escobar, J.S. Higher fecal short-chain fatty acid levels are associated with gut microbiome dysbiosis, obesity, hypertension and cardiometabolic disease risk factors. Nutrients 2018, 11, 51. [CrossRef]

11. LeBlanc, J.G.; Milani, C.; de Giori, G.S.; Sesma, F.; van Sinderen, D.; Ventura, M. Bacteria as vitamin suppliers to their host: A gut microbiota perspective. Curr. Opin. Biotechnol. 2013, 24, 160-168. [CrossRef]

12. Wu, G.D.; Chen, J.; Hoffmann, C.; Bittinger, K.; Chen, Y.Y.; Keilbaugh, S.A.; Bewtra, M.; Knights, D.; Walters, W.A.; Knight, R.; et al. Linking long-term dietary patterns with gut microbial enterotypes. Science 2011, 334, 105-108. [CrossRef] [PubMed]

13. David, L.A.; Maurice, C.F.; Carmody, R.N.; Gootenberg, D.B.; Button, J.E.; Wolfe, B.E.; Ling, A.V.; Devlin, A.S.; Varma, Y.; Fischbach, M.A.; et al. Diet rapidly and reproducibly alters the human gut microbiome. Nature 2014, 505, 559-563. [CrossRef] [PubMed]

14. De Filippo, C.; Cavalieri, D.; Di Paola, M.; Ramazzotti, M.; Poullet, J.B.; Massart, S.; Collini, S.; Pieraccini, G.; Lionetti, P. Impact of diet in shaping gut microbiota revealed by a comparative study in children from Europe and rural Africa. Proc. Natl. Acad. Sci. USA 2010, 107, 14691-14696. [CrossRef] [PubMed]

15. Suez, J.; Korem, T.; Zeevi, D.; Zilberman-Schapira, G.; Thaiss, C.A.; Maza, O.; Israeli, D.; Zmora, N.; Gilad, S.; Weinberger, A.; et al. Artificial sweeteners induce glucose intolerance by altering the gut microbiota. Nature 2014, 514, 181-186. [CrossRef] 
16. Gardner, C.; Wylie-Rosett, J.; Gidding, S.S.; Sen, L.M.; Johnson, R.K.; Reader, D.; Lichtenstein, A.H.; Physical Activity and Metabolism American Heart Association Nutrition Committee of the Council on Nutrition and American Diabetes Association. Nonnutritive sweeteners: Current use and health perspectives: A scientific statement from the american heart association and the american diabetes association. Diabetes Care 2012, 35, 1798-1808. [CrossRef]

17. Blackburn, G.L.; Kanders, B.S.; Lavin, P.T.; Keller, S.D.; Whatley, J. The effect of aspartame as part of a multidisciplinary weight-control program on short- and long-term control of body weight. Am. J. Clin. Nutr. 1997, 65, 409-418. [CrossRef]

18. Suez, J.; Korem, T.; Zilberman-Schapira, G.; Segal, E.; Elinav, E. Non-caloric artificial sweeteners and the microbiome: Findings and challenges. Gut Microbes 2015, 6, 149-155. [CrossRef]

19. Frankenfeld, C.L.; Sikaroodi, M.; Lamb, E.; Shoemaker, S.; Gillevet, P.M. High-intensity sweetener consumption and gut microbiome content and predicted gene function in a cross-sectional study of adults in the united states. Ann. Epidemiol. 2015, 25, 736-742. [CrossRef]

20. Bian, X.; Chi, L.; Gao, B.; Tu, P.; Ru, H.; Lu, K. Gut microbiome response to sucralose and its potential role in inducing liver inflammation in mice. Front. Physiol. 2017, 8, 487. [CrossRef]

21. Bian, X.; Tu, P.; Chi, L.; Gao, B.; Ru, H.; Lu, K. Saccharin induced liver inflammation in mice by altering the gut microbiota and its metabolic functions. Food Chem. Toxicol. 2017, 107, 530-539. [CrossRef] [PubMed]

22. Shil, A.; Olusanya, O.; Ghufoor, Z.; Forson, B.; Marks, J.; Chichger, H. Artificial sweeteners disrupt tight junctions and barrier function in the intestinal epithelium through activation of the sweet taste receptor, T1R3. Nutrients 2020, 12, 1862. [CrossRef]

23. Mohamed, J.A.; Huang, D.B. Biofilm formation by enterococci. J. Med. Microbiol. 2007, 56, 1581-1588. [CrossRef] [PubMed]

24. Tenaillon, O.; Skurnik, D.; Picard, B.; Denamur, E. The population genetics of commensal Escherichia coli. Nat. Rev. Microbiol. 2010, 8, 207-217. [CrossRef] [PubMed]

25. Jimenez, E.; Marin, M.L.; Martin, R.; Odriozola, J.M.; Olivares, M.; Xaus, J.; Fernandez, L.; Rodriguez, J.M. Is meconium from healthy newborns actually sterile? Res. Microbiol. 2008, 159, 187-193. [CrossRef]

26. Mace, O.J.; Affleck, J.; Patel, N.; Kellett, G.L. Sweet taste receptors in rat small intestine stimulate glucose absorption through apical GLUT2. J. Physiol. 2007, 582, 379-392. [CrossRef]

27. Keast, R.S.; Canty, T.M.; Breslin, P.A. Oral zinc sulfate solutions inhibit sweet taste perception. Chem. Senses 2004, 29, 513-521 [CrossRef]

28. Palmnas, M.S.; Cowan, T.E.; Bomhof, M.R.; Su, J.; Reimer, R.A.; Vogel, H.J.; Hittel, D.S.; Shearer, J. Low-dose aspartame consumption differentially affects gut microbiota-host metabolic interactions in the diet-induced obese rat. PLoS ONE 2014, 9, e109841. [CrossRef]

29. Wang, Q.P.; Browman, D.; Herzog, H.; Neely, G.G. Non-nutritive sweeteners possess a bacteriostatic effect and alter gut microbiota in mice. PLoS ONE 2018, 13, e0199080. [CrossRef]

30. Ceri, H.; Olson, M.; Morck, D.; Storey, D.; Read, R.; Olson, B. The MBEC assay system: Multiple equivalent biofilms for antibiotic and biocide susceptibility testing. Methods Enzymol. 2001, 337, 377-385. [CrossRef]

31. Kong, K.F.; Vuong, C.; Otto, M. Staphylococcus quorum sensing in biofilm formation and infection. Int. J. Med. Microbiol. 2006, 296, 133-139. [CrossRef] [PubMed]

32. Wagner, V.E.; Li, L.L.; Isabella, V.M.; Iglewski, B.H. Analysis of the hierarchy of quorum-sensing regulation in Pseudomonas aeruginosa. Anal. Bioanal. Chem. 2007, 387, 469-479. [CrossRef] [PubMed]

33. Hyland, R.M.; Sun, J.; Griener, T.P.; Mulvey, G.L.; Klassen, J.S.; Donnerberg, M.S.; Armstrong, G.D. The bundlin pilin protein of enteropathogenic Escherichia coli is an N-acetyllactosamine-specific lectin. Cell Microbiol. 2008, 10, 177-187. [CrossRef] [PubMed]

34. Oscarsson, J.; Mizunoe, Y.; Li, L.; Lai, X.H.; Wieslander, A.; Uhlin, B.E. Molecular analysis of the cytolytic protein ClyA (SheA) from Escherichia coli. Mol. Microbiol. 1999, 32, 1226-1238. [CrossRef] [PubMed]

35. Saldana, Z.; Erdem, A.L.; Schuller, S.; Okeke, I.N.; Lucas, M.; Sivananthan, A.; Philips, A.D.; Kaper, J.B.; Puente, J.L.; Giron, J.A. The Escherichia coli common pilus and the bundle-forming pilus act in concert during the formation of localized adherence by enteropathogenic E. coli. J. Bacteriol. 2009, 191, 3451-3461. [CrossRef]

36. Huycke, M.M.; Joyce, W.A.; Gilmore, M.S. Enterococcus faecalis cytolysin without effect on the intestinal growth of susceptible enterococci in mice. J. Infect. Dis. 1995, 172, 273-276. [CrossRef]

37. Theilacker, C.; Sanchez-Carballo, P.; Toma, I.; Fabretti, F.; Sava, I.; Kropec, A.; Holst, O.; Huebner, J. Glycolipids are involved in biofilm accumulation and prolonged bacteraemia in Enterococcus faecalis. Mol. Microbiol. 2009, 71, 1055-1069. [CrossRef]

38. Wells, C.L.; Moore, E.A.; Hoag, J.A.; Hirt, H.; Dunny, G.M.; Erlandsen, S.L. Inducible expression of Enterococcus faecalis aggregation substance surface protein facilitates bacterial internalization by cultured enterocytes. Infect. Immun. 2000, 68, 7190-7194. [CrossRef]

39. Sartingen, S.; Rozdzinski, E.; Muscholl-Silberhorn, A.; Marre, R. Aggregation substance increases adherence and internalization, but not translocation, of Enterococcus faecalis through different intestinal epithelial cells in vitro. Infect. Immun. 2000, 68, 6044-6047. [CrossRef]

40. Ludwig, A.; Bauer, S.; Benz, R.; Bergmann, B.; Goebel, W. Analysis of the SlyA-controlled expression, subcellular localization and pore-forming activity of a $34 \mathrm{kDa}$ haemolysin (ClyA) from Escherichia coli K-12. Mol. Microbiol. 1999, 31, 557-567. [CrossRef]

41. Sheikh, J.; Hicks, S.; Dall'Agnol, M.; Phillips, A.D.; Nataro, J.P. Roles for fis and YafK in biofilm formation by enteroaggregative Escherichia coli. Mol. Microbiol. 2001, 41, 983-997. [CrossRef] 
42. Heikens, E.; Bonten, M.J.; Willems, R.J. Enterococcal surface protein esp is important for biofilm formation of Enterococcus faecium E1162. J. Bacteriol. 2007, 189, 8233-8240. [CrossRef]

43. Srivastava, M.; Mallard, C.; Barke, T.; Hancock, L.E.; Self, W.T. A selenium-dependent xanthine dehydrogenase triggers biofilm proliferation in Enterococcus faecalis through oxidant production. J. Bacteriol. 2011, 193, 1643-1652. [CrossRef] [PubMed]

44. Shankar, N.; Baghdayan, A.S.; Gilmore, M.S. Modulation of virulence within a pathogenicity island in vancomycin-resistant Enterococcus faecalis. Nature 2002, 417, 746-750. [CrossRef]

45. Giaffer, M.H.; Holdsworth, C.D.; Duerden, B.I. Virulence properties of Escherichia coli strains isolated from patients with inflammatory bowel disease. Gut 1992, 33, 646-650. [CrossRef]

46. Ike, Y.; Hashimoto, H.; Clewell, D.B. High incidence of hemolysin production by Enterococcus (streptococcus) faecalis strains associated with human parenteral infections. J. Clin. Microbiol. 1987, 25, 1524-1528. [CrossRef] [PubMed]

47. Mirsepasi-Lauridsen, H.C.; Du, Z.; Struve, C.; Charbon, G.; Karczewski, J.; Krogfelt, K.A.; Petersen, A.M.; Wells, J.M. Secretion of alpha-hemolysin by Escherichia coli disrupts tight junctions in ulcerative colitis patients. Clin. Transl. Gastroenterol. 2016, 7, e149. [CrossRef] [PubMed]

48. Nelson, G.; Hoon, M.A.; Chandrashekar, J.; Zhang, Y.; Ryba, N.J.; Zuker, C.S. Mammalian sweet taste receptors. Cell 2001, 106, 381-390. [CrossRef]

49. Wee, M.; Tan, V.; Forde, C. A comparison of psychophysical dose-response behaviour across 16 sweeteners. Nutrients 2018, 10, 1632. [CrossRef] [PubMed]

50. Nijland, R.; Burgess, J.G. Bacterial olfaction. Biotechnol. J. 2010, 5, 974-977. [CrossRef]

51. Bandyopadhyay, A.; Ghoshal, S.; Mukherjee, A. Genotoxicity testing of low-calorie sweeteners: Aspartame, acesulfame-K., and saccharin. Drug Chem. Toxicol. 2008, 31, 447-457. [CrossRef] [PubMed]

52. Qu, Y.; Li, R.; Jiang, M.; Wang, X. Sucralose increases antimicrobial resistance and stimulates recovery of Escherichia coli mutants Curr. Microbiol. 2017, 74, 885-888. [CrossRef] [PubMed]

53. Rencuzogullari, E.; Tuylu, B.A.; Topaktas, M.; Ila, H.B.; Kayraldiz, A.; Arslan, M.; Diler, S.B. Genotoxicity of aspartame. Drug Chem. Toxicol. 2004, 27, 257-268. [CrossRef]

54. Yu, Z.; Wang, Y.; Lu, J.; Bond, P.L.; Guo, J. Nonnutritive sweeteners can promote the dissemination of antibiotic resistance through conjugative gene transfer. ISME J. 2021. [CrossRef] [PubMed]

55. Frey, R.L.; He, L.; Cui, Y.; Decho, A.W.; Kawaguchi, T.; Fergusonm, P.L.; Ferry, J.L. Reaction of N-acylhomoserine lactones with hydroxyl radicals: Rates, products, and effects on signaling activity. Environ. Sci. Technol. 2010, 44, 7465-7469. [CrossRef]

56. Rothfork, J.M.; Timmins, G.S.; Harris, M.N.; Chen, X.; Lusis, A.J.; Otto, M.; Cheung, A.L.; Gresham, D. Inactivation of a bacterial virulence pheromone by phagocyte-derived oxidants: New role for the NADPH oxidase in host defense. Proc. Natl. Acad. Sci. USA 2004, 101, 13867-13872. [CrossRef]

57. Ghoshal, U.C.; Ghoshal, U.; Jain, M.; Kumar, A.; Aggarwal, R.; Misra, A.; Ayyagari, A.; Naik, S.R. Strongyloides stercoralis infestation associated with septicemia due to intestinal transmural migration of bacteria. J. Gastroenterol. Hepatol. 2002, 17, 1331-1333. [CrossRef]

58. Wells, C.L.; Jechorek, R.P.; Erlandsen, S.L. Evidence for the translocation of Enterococcus faecalis across the mouse intestinal tract. J. Infect. Dis. 1990, 162, 82-90. [CrossRef]

59. Wells, C.L.; Erlandsen, S.L. Localization of translocating Escherichia coli, proteus mirabilis, and Enterococcus faecalis within cecal and colonic tissues of monoassociated mice. Infect. Immun. 1991, 59, 4693-4697. [CrossRef]

60. Santos, P.S.; Caria, C.R.P.; Gotardo, E.M.F.; Ribeiro, M.L.; Pedrazzoli, J.; Gambero, A. Artificial sweetener saccharin disrupts intestinal epithelial cells' barrier function in vitro. Food Funct. 2018, 9, 3815-3822. [CrossRef]

61. Yang, Y.Y.; Liu, W.R.; Liu, Y.S.; Zhao, J.L.; Zhang, Q.Q.; Zhang, M.; Zhang, J.N.; Jiang, Y.X.; Zhang, L.J.; Ying, G.G. Suitability of pharmaceuticals and personal care products (PPCPs) and artificial sweeteners (ASs) as wastewater indicators in the pearl river delta, south china. Sci. Total Environ. 2017, 590-591, 611-619. [CrossRef]

62. Tran, N.H.; Hu, J.; Li, J.; Ong, S.L. Suitability of artificial sweeteners as indicators of raw wastewater contamination in surface water and groundwater. Water Res. 2014, 48, 443-456. [CrossRef]

63. Tran, N.H.; Gan, J.; Nguyen, V.T.; Chen, H.; You, L.; Duarah, A.; Zhang, L.; Gin, K.Y. Sorption and biodegradation of artificial sweeteners in activated sludge processes. Bioresour. Technol. 2015, 197, 329-338. [CrossRef] [PubMed]

64. Hall-Stoodley, L.; Costerton, J.W.; Stoodley, P. Bacterial biofilms: From the natural environment to infectious diseases. Nat. Rev. Microbiol. 2004, 2, 95-108. [CrossRef] [PubMed]

65. Lleo, M.; Bonato, B.; Tafi, M.C.; Caburlotto, G.; Benedetti, D.; Canepari, P. Adhesion to medical device materials and biofilm formation capability of some species of enterococci in different physiological states. FEMS Microbiol. Lett. 2007, 274, 232-237. [CrossRef] [PubMed]

66. Mack, D.; Rohde, H.; Harris, L.G.; Davies, A.P.; Horstkotte, M.A.; Knobloch, J.K. Biofilm formation in medical device-related infection. Int. J. Artif. Organs. 2006, 29, 343-359. [CrossRef] [PubMed]

67. Braxton, E.E.; Ehrlich, G.D.; Hall-Stoodley, L.; Stoodley, P.; Veeh, R.; Fux, C.; Hu, F.Z.; Quigley, M.; Post, J.C. Role of biofilms in neurosurgical device-related infections. Neurosurg. Rev. 2005, 28, 249-255. [CrossRef]

68. Burton, E.; Yakandawala, N.; LoVetri, K.; Madhyastha, M.S. A microplate spectrofluorometric assay for bacterial biofilms. J. Ind. Microbiol. Biotechnol. 2007, 34, 1-4. [CrossRef]

69. Wiseman, G.M. The hemolysins of Staphylococcus aureus. Bacteriol. Rev. 1975, 39, 317-344. [CrossRef] [PubMed] 
70. Darfeuille-Michaud, A.; Aubel, D.; Chauviere, G.; Rich, C.; Bourges, M.; Servin, A.; Joly, B. Adhesion of enterotoxigenic Escherichia coli to the human colon carcinoma cell line caco-2 in culture. Infect. Immun. 1990, 58, 893-902. [CrossRef]

71. Inaba, H.; Nomura, R.; Kato, Y.; Takeuchi, H.; Amano, A.; Asai, F.; Nakano, K.; Lamont, R.J.; Matsumoto-Nakano, M. Adhesion and invasion of gingival epithelial cells by Porphyromonas gulae. PLoS ONE 2019, 14, e0213309. [CrossRef] [PubMed]

72. Figueiredo, P.M.; Furumura, M.T.; Santos, A.M.; Sousa, A.C.; Kota, D.J.; Levy, C.E.; Yano, T. Cytotoxic activity of clinical Stenotrophomonas maltophilia. Lett. Appl. Microbiol. 2006, 43, 443-449. [CrossRef] [PubMed] 